\title{
Residual effect of mixture of glyphosate and 2,4-D in winter maize in different soil textures
}

\author{
Schaianne A. Gomes ${ }^{1}$, Sayonara A. do C. M. Arantes ${ }^{1}$, Ednaldo A. de Andrade ${ }^{1}$, \\ Kelte R. Arantes ${ }^{1}$, Daniela N. Viana ${ }^{1} \&$ Cezar da C. Pereira Junior ${ }^{1}$ \\ ${ }^{1}$ Universidade Federal de Mato Grosso/Instituto de Ciências Agrárias e Ambientais/Unidade Acadêmica de Engenharia Agronômica. Sinop, MT. E-mail: \\ schaianne_alves@hotmail.com (Corresponding author); sayocm@ufmt.br; ednaldo@ufmt.br; keltearantes@gmail.com; danni_norberto@hotmail.com; \\ cezarjunior91@hotmail.com
}

\section{Key words:}

phytotoxicity

herbicides

Red Yellow Latosol

Quartzarenic Neosol

\begin{abstract}
A B S T R A C T
To increase the efficiency in the control of weeds, it is common the use of a mixture of the herbicides glyphosate and 2,4-D in the desiccation. This paper aimed to evaluate the residual effect of these two herbicides on the development of maize plants, in soils of different textures. The experiment was conducted in a greenhouse, in 2015 , in a completely randomized design in a $2 \times 2 \times 7$ factorial scheme, corresponding to two soils (Red Yellow Latosol and Quartzarenic Neosol), two herbicide application times (5 and 10 days before maize sowing) and seven doses of herbicides (recommended dose of glyphosate, recommended dose of 2,4-D; mixing the recommended doses of glyphosate and 2,4-D; two, ten and fifty times the recommended doses in admixture; and one control), with 4 replicates. After emergence of maize plants, the following variables were evaluated: phytotoxicity, plant height, chlorophyll a and chlorophyll $b$, shoot fresh and dry matter and root dry matter. In general, there was lower residual effect on the Red Yellow Latosol at all the doses of the herbicides and in the interval of 10 days between the desiccation and sowing.
\end{abstract}

\section{Palavras-chave: \\ fitotoxicidade \\ herbicidas \\ Latossolo Vermelho Amarelo \\ Neossolo Quartzarênico}

\section{Efeito residual da mistura glifosato e 2,4-D em milho "safrinha" em solos de diferentes texturas}

\section{R E S U M O}

Para aumentar a eficiência no controle de plantas daninhas é comum o uso em dessecação da mistura dos herbicidas glifosato e 2,4-D. Objetivou-se, neste trabalho, avaliar o efeito residual da aplicação desses dois herbicidas sobre o desenvolvimento de plantas de milho em solos de diferentes texturas. O experimento foi conduzido em casa de vegetação, no ano de 2015, em delineamento inteiramente casualizado, no esquema fatorial $2 \times 2 \times 7$, sendo dois solos (Latossolo Vermelho Amarelo e Neossolo Quartzarênico), duas épocas de aplicação dos herbicidas (5 e 10 dias antes da semeadura do milho) e sete doses dos herbicidas (dose recomendada de glifosato; dose recomendada de 2,4-D; mistura das doses recomendadas de glifosato e 2,4-D; duas, dez e cinquenta vezes as doses recomendadas em mistura e uma testemunha), com quatro repetições. Após a emergência das plantas de milho foram avaliados os seguintes parâmetros: fitotoxicidade, altura de plantas, clorofilas a e b, massa fresca e seca da parte aérea e massa seca da raiz. Em geral, ocorreu menor efeito residual no Latossolo Vermelho Amarelo em todas as doses dos herbicidas e no intervalo de 10 dias entre a aplicação e a semeadura. 


\section{INTRODUCTION}

With the advent of genetically modified plants for the resistance to herbicides, glyphosate has gained wide space in the management of weeds. According to Serra et al. (2011), the technology of transgenics has considerably increased the use of the herbicide glyphosate, especially in post-emergence, since it is applied three to four times during the soybean cycle.

Due to the wide use of the herbicide glyphosate, nowadays there is a large number of plants with total or partial resistance to it, such as: Amaranthus viridis, Bidens pilosa, Commelina benghalensis L., Conyza bonariensis, Cyperus rotundus, Euphorbia heterophylla L., Ipomoea sp., Senna occidentalis and Spermacoce latifolia (Takano et al., 2013).

The tolerance and/or resistance of certain species of weeds to the herbicide glyphosate has led farmers to associate herbicides with different active ingredients in the desiccation, as crop management. The herbicide 2,4-D has been one of the most used in association with glyphosate and, according to Takano et al. (2013), the addition of 2,4-D to the glyphosate is determinant to accelerate and improve the control of weeds considered as of hard control.

However, glyphosate can also be used in combination with other herbicides in the management of the crop, such as chlorimuron-ethyl, diclosulam, imazethapyr, metsulfuron-methyl, paraquat + diuron and isolated ammonium glufosinate (Rodrigues \& Almeida, 2005; Petter et al., 2007; Takano et al., 2013).

It is known that the attributes that most influence the dynamics of herbicides in the soil are: clay content and type, organic matter content, $\mathrm{pH}$, apparent density and pore size and distribution. The understanding about the effect of these attributes on the behavior of herbicides can lead to the adequacy of doses according to the specific characteristics of the soil (Inoue et al., 2007). In addition, soil attributes can influence the sorption and desorption of herbicides, thus depending on the interaction of these processes, with a possible residual effect on the crop cultivated after soybean, such as second-season maize (Arantes et al., 2014).

The succession of crops has been widely used in Brazil, especially in Mato Grosso, but little has been done to evaluate the residual effect of the herbicides used in the soybean crop on the subsequent crop (Dan et al., 2011).

Thus, this study aimed to evaluate the residual effect of the herbicides glyphosate, 2,4-D and increasing doses of the mixture glyphosate $+2,4-\mathrm{D}$ in the desiccation performed at the end of the soybean crop on the maize crop cultivated in succession in soils of different textures (Red Yellow Latosol and Quartzarenic Neosol).

\section{Material AND Methods}

The experiment was conducted in completely randomized design, in a $2 \times 2 \times 7$ factorial scheme, corresponding to two soils (Red Yellow Latosol and Quartzarenic Neosol), two maize sowing times ( 5 and 10 days after desiccation) and 7 doses of the herbicides, with four replicates.

The results were subjected to the analysis of variance using the program Sisvar (Ferreira, 2011) and, in case of significant differences, the Scott-Knott test at 0.05 probability level was applied for the comparison of means.

The experiment was carried out in 2015 in a greenhouse, for approximately 130 days. Two forest soils were collected: Red Yellow Latosol (LVA) and Quartzarenic Neosol (RQ), in the superficial layer of $0-20 \mathrm{~cm}$. The soil samples were air-dried and sieved through a $4-\mathrm{mm}$ mesh. Then, soil samples were collected and taken to the laboratory for chemical and physical characterization (Tables 1 and 2, respectively), according to the methodology proposed by EMBRAPA (1997).

The soils were placed in pots with capacity for $7 \mathrm{~L}$ and, based on the results of the analyses of soil attributes, correction was performed to increase base saturation to $65 \%$, besides incubation with "filler" limestone $(\mathrm{RNV}=99.16 \%)$, waiting for 90 days. After this period, fertilization was performed and the soybean cultivar AN8500 was planted. For soybean fertilization, the following fertilizers were incorporated to the soil: monoammonium phosphate (MAP) and potassium chloride $(\mathrm{KCl})$. Three soybean seeds were planted in each pot, with subsequent thinning after emergence, maintaining only one seedling per pot. Plants were maintained until the end of the cycle for the desiccation to be similar to that under field conditions.

The desiccation with the herbicides glyphosate (commercial product Glifoxin $360 \mathrm{~g} \mathrm{~L}^{-1}$ acid equivalent (a.e.)) and 2,4-D (commercial product 2,4-D Amina $72^{\circ} 698 \mathrm{~g} \mathrm{~L}^{-1}$ a.e.) was performed at the end of the soybean cycle, maintaining the straw in the pots. Desiccation was performed using a backpack sprayer pressurized with carbon dioxide $\left(\mathrm{CO}_{2}\right)$, with a nozzle of 110015 spraying points. The utilized service pressure was $2 \mathrm{kgf} \mathrm{cm}^{2}$, promoting a spray volume of $150 \mathrm{~L} \mathrm{ha}^{-1}$.

The doses of herbicides used in the desiccation were: recommended dose $(\mathrm{RD})$ of $2.5 \mathrm{~L} \mathrm{ha}^{-1}$ of glyphosate $(0.9 \mathrm{~kg}$ ha $^{-1}$ a.e.) (G); the $\mathrm{RD}$ of $1 \mathrm{~L} \mathrm{ha}^{-1}$ of $2,4-\mathrm{D}\left(0.698 \mathrm{~kg} \mathrm{ha}^{-1}\right.$ a.e.) (D); RD in mixture of glyphosate and 2,4-D (M); two times the $\mathrm{RD}$ in mixture of the herbicides (glyphosate $\left(1.8 \mathrm{~kg} \mathrm{ha}^{-1}\right.$ a.e.) and 2,4-D (1.39 $\mathrm{kg} \mathrm{ha}^{-1}$ a.e.)) (M2); ten times the RD in mixture of glyphosate (9 $\mathrm{kg} \mathrm{ha}^{-1}$ a.e.) and 2,4-D (6.98 $\mathrm{kg} \mathrm{ha}^{-1}$ a.e.) (M10); fifty times the RD in mixture of glyphosate (45 $\mathrm{kg} \mathrm{ha}^{-1}$ a.e.) and 2,4-D (34.9 $\mathrm{kg} \mathrm{ha}^{-1}$ a.e.) (M50); and a control. Maize sowing was performed at 5 and 10 days after application

Table 2. Granulometry and textural class of the Red Yellow Latosol (LVA) and Quartzarenic Neosol (RQ)

\begin{tabular}{ccccc}
\hline Soil & Sand & Silt & Clay & Textural \\
\cline { 2 - 4 } Llass \\
LVA & 296.5 & 140.5 & 563.0 & Clay \\
RQ & 885.0 & 30.5 & 84.5 & Sand \\
\hline
\end{tabular}

Table 1. Chemical attributes of the Red Yellow Latosol (LVA) and Quartzarenic Neosol (RQ)

\begin{tabular}{|c|c|c|c|c|c|c|c|c|c|c|c|c|}
\hline \multirow{2}{*}{ Soil } & \multirow{2}{*}{$\begin{array}{c}\mathrm{pH} \\
\mathrm{H}_{2} \mathrm{O}\end{array}$} & $P$ & $K$ & $\mathrm{Ca}$ & $\mathrm{Mg}$ & $\overline{A I}$ & $\bar{H}$ & SB & $T$ & $t$ & \multirow{2}{*}{ V\% } & \multirow{2}{*}{$\begin{array}{c}0 \mathrm{M} \\
\mathrm{g} \mathrm{dm}^{-3}\end{array}$} \\
\hline & & \multicolumn{2}{|c|}{$\mathrm{mg} \mathrm{dm}^{-3}$} & \multicolumn{7}{|c|}{$\mathrm{cmol}_{\mathrm{c}} \mathrm{dm}^{-3}$} & & \\
\hline LVA & 4.25 & 1.35 & 37 & 1.55 & 0.67 & 0.10 & 4.93 & 2.31 & 7.34 & 2.41 & 31.47 & 39.97 \\
\hline $\mathrm{RQ}$ & 4.46 & 0.55 & 11 & 0.06 & 0.05 & 0.95 & 3.75 & 0.13 & 4.83 & 1.08 & 2.69 & 18.59 \\
\hline
\end{tabular}

SB - Sum of bases; T - Potential CEC; $\mathrm{t}$ - Effective CEC; V\% - Base saturation; OM - Organic matter 
of the herbicides. Three maize seeds were planted in each pot, with subsequent thinning after emergence, leaving only one maize seedling in each pot.

After the maize cultivar Celeron was sown, the following parameters were evaluated at 7,20 and 34 days after emergence (DAE): plant height $(\mathrm{cm})$, contents of chlorophyll a and chlorophyll b and phytotoxicity (\%). Plant height was measured from the soil to the last leaf insertion with the fully open leaf, which was also evaluated for the chlorophyll content using a Falker chlorophyll meter, which determines the contents of chlorophyll a and b.

Phytotoxicity was visually evaluated, using the methodology and scale of scores of EWRC (1964). The phytotoxicity scores were: 0 (without symptoms), 1.5 (very light), 2 (light), 2.5 (moderate), 3 (medium), 3.5 (almost strong), 4 (strong), 4.5 (very strong) and 5 (plant death).

At 34 days after emergence, maize plants were evaluated for shoot fresh and dry matter and root dry matter. All plants were cut in the collar, separating shoots from roots. Shoots and roots were dried in a forced-air oven at $65^{\circ} \mathrm{C}$ and weighed to obtain the dry matter of shoots and roots of the maize plants.

\section{Results AND Discussion}

The residual effect was expressed through the phytotoxicity in maize plants, especially in those sown at 5 days after desiccation, in all days of evaluation and only for doses with the presence of 2,4-D, corroborating the results of Silva et al. (2011). According to these authors, for the use of 2,4-D in direct sowing management, one must wait at least 10 days between herbicide application and sowing, also confirming the recommendations of EMBRAPA (2002).

The highest values of phytotoxicity were observed when plants were cultivated in the RQ soil. The sorption of the herbicides glyphosate and 2,4-D in this soil was possibly lower than in the LVA, since the LVA has clayey texture and greater amount of retention sites due to the larger amount and diversity of oxides and of silicates and organic matter. In the sandy soil (RQ), the herbicides were probably more available in the soil solution, allowing their absorption by plant roots, which explains the greater residual effect on the maize crop.

Oliveira Júnior \& Regitano (2009) claim that clayey soils, in general, have higher potential of sorption of the molecules of the herbicides, while Silva et al. (2011) concluded that the residual effect of 2,4-D becomes more evident in mediumtextured soil compared with one of clayey texture, since soils with higher contents of organic matter have grater sorption of 2,4-D.

The toxicity of 2,4-D was evidenced by the epinasty of the leaves, bending of the leaf over the bottom side and the stems bent toward the soil. It can be observed that the recommended dose of glyphosate did not cause visible phytotoxicity in maize plants, because glyphosate is a molecule strongly sorbed to soil particles (Veiga et al., 2001).

There was significant difference between the doses of the herbicides in the different soils, only for the maize sowing performed 5 days after desiccation, for all days of evaluation (Figure 1).
A.

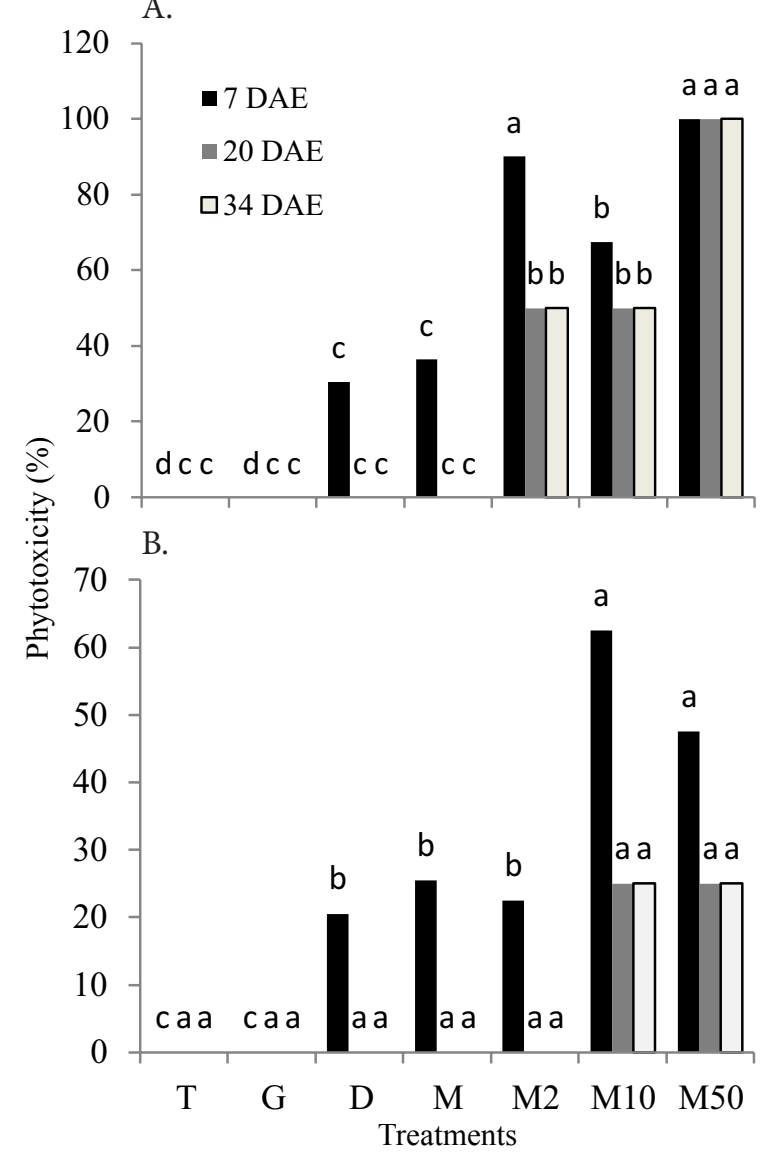

T - Control; G - RD glyphosate. D - RD 2,4-D; M - RD in mixture of glyphosate and 2,4-D; M2, M10 and $\mathrm{M} 50-2,10$ and 50 times the RD in mixture of glyphosate and 2,4-D; RD - Recommended dose Means followed by the same letter for each day of evaluation after emergence (DAE) do not differ by Scott-Knott test at 0.05 probability level, for each graph, inside the treatments Figure 1. Means of maize phytotoxicity in relation to the doses of the herbicides glyphosate and 2,4-D in the Quartzarenic Neosol (RQ) (A) and Red Yellow Latosol (LVA) (B), for the sowing 5 days after application

The association of these herbicides caused residual effect on maize plants, because the highest doses of the mixture of pesticides led to highest phytotoxicity observed. However, maize plants showed injuries only in the first stages, exhibiting recovery of the damages favored by the residual of the herbicides along the development cycle.

Maize plants cultivated in the LVA showed higher values of height in all days of evaluation (Figure 2), suggesting that

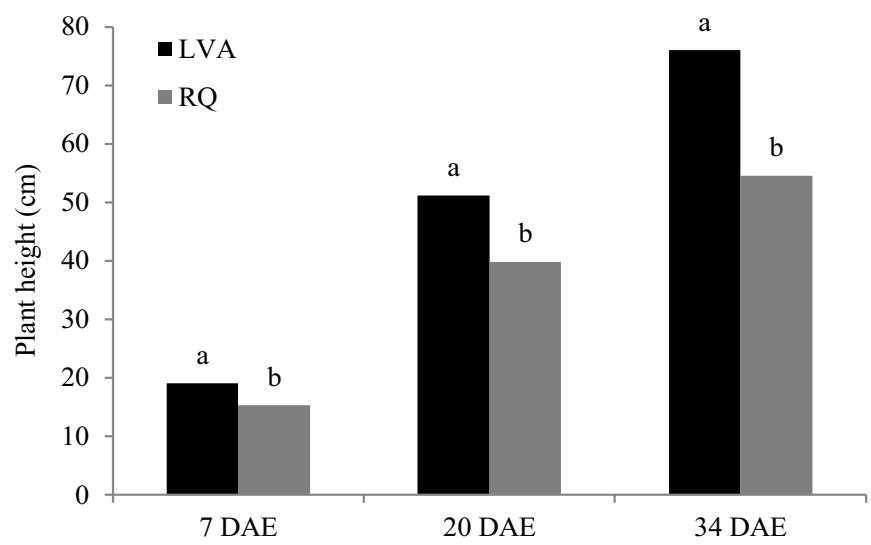

Means followed by the same letter, for each day of evaluation after emergence (DAE), do not differ by Scott-Knott at 0.05 probability level

Figure 2. Mean height of maize plants in the Red Yellow Latosol (LVA) and Quartzarenic Neosol (RQ) 
this soil promoted better conditions for the development of the crop, regardless of the doses and periods of evaluation. This fact is explained by the physical and chemical attributes of the soils and herbicides studied. The herbicides were more sorbed to the LVA, because it is a clayey soil with higher contents of organic matter and retention sites, and since the herbicides were less available in this soil, the residual effect was lower, leading to taller maize plants.

At the highest doses of the mixture of herbicides, maize plants grew less, possibly because of the greater residual effect of these molecules in the soil. Similar results were observed by Reis et al. (2010), who studied the phytotoxic effects of the herbicide 2,4-D on maize in pre- and post-emergence applications, and found that, with the increase of doses in pre-emergence, plants tended to reduce their size, while in the post-emergence application plants showed greater values of height. Velini et al. (2008) report that the application of high doses of glyphosate inhibit plant growth, while low doses can stimulate it.

In all evaluations, the highest values of chlorophyll a and chlorophyll b were observed in plants cultivated in the LVA (Figure 3). Since this soil promoted better conditions for maize development, this fact can be explained by the physical and chemical attributes of the soils and herbicides studied, evidencing that in RQ the residual effect of the herbicides on maize was higher.

According to Santos et al. (1999), the biosynthesis of chlorophyll and the development of chloroplasts can be inhibited by herbicides that interfere with structures of the chloroplasts, leading to the loss of this pigment. Besides the interference in the synthesis of chlorophyll, these compounds can also affect the formation of other pigments.

Hertwig (1983) reports that 2,4-D has systemic action and acts in the deregulation of plant metabolism, leading to death. In addition, it causes epinasty, characterized by the downward bending of the leaf, decreasing the surface for light absorption, leading to disorders in the synthesis of proteins and collapse of tissue (Giafagna, 1987).

The herbicide glyphosate, for being a phosphonic acid, can act in the direct degradation of chlorophyll a, through demetallation, forming complex with the magnesium ion, and in the indirect degradation, through immobilization of magnesium and manganese, necessary for the formation of chlorophyll and photosynthesis, respectively (Bernards et al., 2005).

Kitchen et al. (1981) observed harmful effect caused by glyphosate on the synthesis of aminolevulinic acid (ALA), a precursor in the biosynthesis of chlorophylls a and b, since both enzymes responsible for their biosynthesis, catalase and peroxidase, are very sensitive to the deficiency of iron, which is one of the elements that can be chelated by glyphosate.

There was difference in the data obtained for shoot fresh matter (SFM), shoot dry matter (SDM) and root dry matter (RDM) between the soils (Table 3 ).

In the LVA, the values of SFM, SDM and RDM were higher, because of the greater plant height and lower phytotoxicity, suggesting that maize plants showed better development in this soil, regardless of the doses of the herbicides and intervals
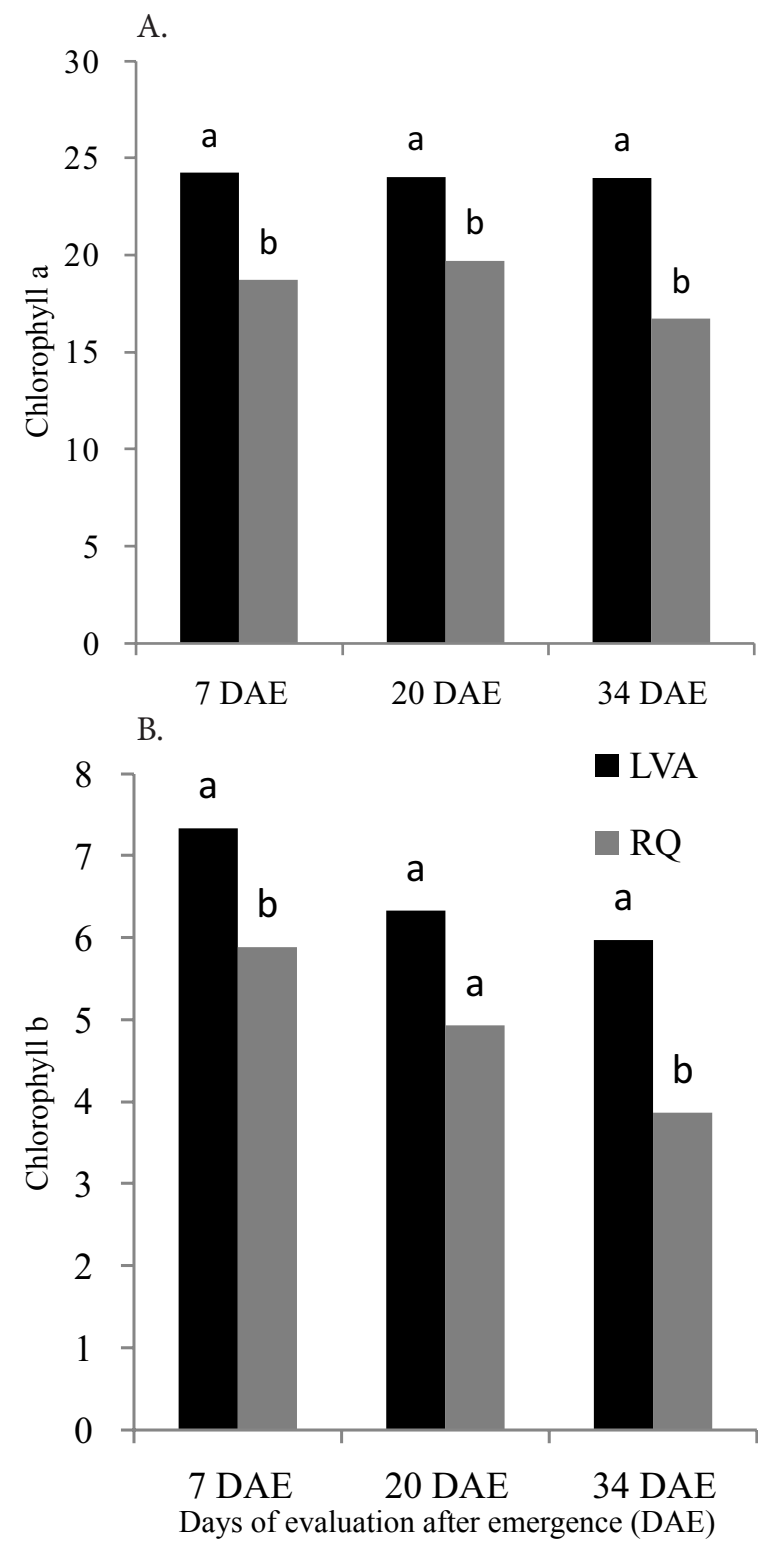

Means followed by the same letter for each day of evaluation after emergence (DAE) do not differ by Scott-Knott test at 0.05 probability level

Figure 3. Mean of the contents of chlorophyll a (A) and chlorophyll b (B) in maize plants, in Red Yellow Latosol (LVA) and Quartzarenic Neosol (RQ)

Table 3. Shoot fresh matter (SFM), shoot dry matter (SDM) and root dry matter (RDM) in g of maize plants, in the Red Yellow Latosol (LVA) and Quartzarenic Neosol (RQ)

\begin{tabular}{cccc}
\hline Soil & SFM & SDM & RDM \\
LVA & $29.90 \mathrm{a}$ & $4.58 \mathrm{a}$ & $2.31 \mathrm{a}$ \\
RQ & $12.70 \mathrm{~b}$ & $1.94 \mathrm{~b}$ & $1.07 \mathrm{~b}$ \\
\hline
\end{tabular}

Means followed by the same letter in the column do not differ by Scott-Knott test at 0.05 probability level

between the desiccation at the end of the soybean cycle and maize sowing. Thus, the residual effect of the herbicides was lower in the LVA, possibly because of the greater sorption of the herbicides in this soil. Similar results were observed in studies conducted by Casonatto et al. (2014), who evaluated the effects of the herbicide glyphosate on transgenic soybean, in soils of varied textures under different levels of phosphorus, evidencing that there was trend of greater shoot fresh and dry biomass of soybean plants in the LVA, compared with the RQ, for all levels of phosphorus. 


\section{Conclusions}

1. There is residual effect of 2,4-D and the mixture of glyphosate and 2,4-D in the Quartzarenic Neosol and Red Yellow Latosol, in a more pronounced way in the former.

2. The residual effect of the herbicides on the soil is higher for maize plants sown 5 days after desiccation.

3. The residual of increasing doses of the mixtures of the herbicides glyphosate and 2,4-D on maize plants causes increase in phytotoxicity, plants with smaller size and low contents of chlorophyll a and chlorophyll b.

4. The highest values of shoot fresh and dry matter and root dry matter were observed in the Red Yellow Latosol, regardless of the doses and days of application.

\section{ACKNOWLEDgments}

The authors thank the Mato Grosso Research Support Foundation (FAPEMAT), for granting the master's scholarship to the first author.

\section{Literature Cited}

Arantes, S. A. C. M.; Zimpel, G. Q.; Arantes, K. R.; Botelho, F. B. S.; Cassol, J. A. Efeito residual do glyphosate em solos de dierentes texturas avaliado pelo método de bioensaio. Revista de Ciências Agroambientais, v.12, p.57-64, 2014.

Bernards, M. L.; Thelen, K. D.; Penner, D.; Muthukumaran, R. B.; McCracken, J. L. Glyphosate interaction with manganese in tank mixtures and its effect on glyphosate absorption and translocation. Weed Science, v.53, p.787-794, 2005. https://doi.org/10.1614/ WS-05-043R.1

Casonatto, M. S.; Arantes, S. A. C. M.; Rieger, E. A.; Andrade, E. A. How glyphosate may affect transgenic soybean in different soil and phosphorus levels. Planta Daninha, v.32, p.843-850, 2014. https://doi.org/10.1590/S0100-83582014000400019

Dan, H. A.; Dan, L. G. M.; Barroso, A. L.; Procópio, S. O.; Oliveira Júnior, R. S.; Assis, R. L.; Silva, A. G.; Feldkircher, C. Atividade residual de herbicidas pré-emergentes aplicados na cultura da soja sobre o milheto cultivado em sucessão. Planta Daninha, v.29, p.437-445, 2011. https://doi.org/10.1590/S010083582011000200022

EMBRAPA - Empresa Brasileira de Pesquisa Agropecuária. Centro Nacional de Pesquisa de Solos. Manual de métodos de análise de solo. 2.ed. Rio de Janeiro: EMBRAPA, 1997. 212p.

EMBRAPA - Empresa Brasileira de Pesquisa Agropecuária. Tecnologia de dessecação de plantas daninhas no sistema plantio direto. Dourados: Embrapa Agropecuária Oeste, 2002. 6p. Circular Técnica 10

EWRC - European Weed Research Council. Report of the $3^{\text {rd }}$ and $4^{\text {th }}$ meetings of EWRC Comittee of Methods in Weed Research. Weed Research, v.4, p.88, 1964.

Ferreira, D. F. Sisvar: A computer statistical analysis system. Ciência e Agrotecnologia, v.35, p.1039-1042, 2011.
Giafagna, T. J. Natural and synthetic growth regulators and their use in horticultural agronomic crops. In: Davies, P. J. (ed.). Plant hormones and their role in plant growth and development. Dordrecht: Kluwer, 1987. Cap.19, p.614-634.

Hertwig, V. K. O uso de herbicidas. Manual de herbicidas desfolhantes, fitorreguladores e bio-estimulantes, 2.ed. São Paulo: Agronômica Ceres, 1983. p.46-50.

Inoue, M. H.; Oliveira Júnior, R. S.; Constantin, J.; Alonso, D. G. Potencial de lixiviação de Imazac e Isoxaflutole em colunas de solo. Planta Daninha, v.25, p.547-555, 2007. https://doi.org/10.1590/ S0100-83582007000300014

Kitchen, L. M.; Witt, W. W.; Rieck, C. E. Inhibition of aminolevulic acid synthesis by glyphosate. Weed Science, v.29, p.571-577, 1981.

Oliveira Júnior, R. S.; Regitano, J. B. Dinâmica de pesticidas no solo. In: Melo, V. F.; Alleoni, L. R. F. (ed.) Química e mineralogia do solo. Viçosa: Sociedade Brasileira de Ciência do Solo, 2009. p.187-248.

Petter, F. A.; Procópio, S. O.; Cargnelutti Filho, A.; Barroso, A. L. L.; Pacheco, L. P. Manejo de herbicidas na cultura da soja Roundup Ready. Planta Daninha, v.25, p.557-566, 2007. https://doi. org/10.1590/S0100-83582007000300015

Reis, T. C.; Santos, T. S.; Andrade, A. P.; Neves, A. F. Efeitos de fitotoxicidade do herbicida 2,4-D no milho em aplicações pré e pós-emergência. Revista de Biologia e Ciências da Terra, v.10, p.25-33, 2010.

Rodrigues, B. N.; Almeida, F. S. Guia de herbicidas. 5.ed. Londrina: Grarfmake, 2005. 592p.

Santos, D. M. M. dos; Pitelli, R. A.; Banzatto, D. A. Efeitos de herbicidas nos teores de clorofilas de Spirodela punctata. Planta Daninha, v.17, p.175-182, 1999. https://doi.org/10.1590/S010083581999000200001

Serra, A. P.; Marchetti, M. E.; Candido, A. C. S.; Dias, A. C. R; Christoffoleti, P. J. Influência do glifosato na eficiência nutricional do nitrogênio, manganês, ferro, cobre e zinco em soja resistente ao glifosato. Ciência Rural, v.41, p.77-84, 2011. https://doi. org/10.1590/S0103-84782011000100013

Silva, F. M. L.; Cavalieri, S. D.; Jose, A. R. S.; Ulloa, S. M.; Velini, E. D. Atividade residual de 2,4-D sobre a emergência de soja em solos com texturas distintas. Revista Brasileira de Herbicidas, v.10, p.29-36, 2011. https://doi.org/10.7824/rbh.v10i1.85

Takano, H. K.; Oliveira Júnior, R. S. de; Constantin, J.; Biffe, D. F.; Franchini, L. H. M.; Braz, G. B. P.; Rios, F. A.; Gheno, E. A.; Gemelli, A. Efeito da adição do 2,4-D ao glyphosate para o controle de espécies de plantas daninhas de difícil controle. Revista Brasileira de Herbicidas, v.12, p.1-13, 2013. https://doi. org/10.7824/rbh.v12i1.207

Veiga, F.; Zapatta, J. M.; Marcos, F.; Alvarez, E. Dynamics of glyphosate and aminomethylphosphonic acid in a forest soil in Galicia, north-west Spain. The Science of the Total Environment, v.271, p.135-144, 2001. https://doi.org/10.1016/S0048-9697(00)00839-1

Velini, E. D.; Alves, E.; Godoy, M. C.; Meschede, D. K.; Souza, R. T.; Duke, S. O. Glyphosate applied at low doses can stimulate plant growth. Pest Management Science, v.64, p.489-496, 2008. https:// doi.org/10.1002/ps.1562 